\title{
Effect of soil moisture level and phosphorus rate on phosphorus uptake and growth of corn (Zea mays L.)'
}

\author{
Miguel A. Muñoz and Trevor G. Arscott"
}

\begin{abstract}
The effect of soil moisture level and phosphorus fertilization on corn (Zea mays L.) growth and P uptake was evaluated in a pot experiment under greenhouse conditions. Two soils, Lewisburg silf loam (fine, mixed, mesic, Typic Hapludalf) and Nipe clay (clayey, oxidic, isohyperthermic, Anionic Acrudox) were included in the study. The three moisture levels were $M_{1}=$ field capacity, $M_{2}=$ fluctuation between field capacity and $50 \%$ available water, and $M_{3}=$ fluctuation between field capacity and permanent wilting point. The phosphorus treatments were $P_{1}=0 \mathrm{~kg} P / \mathrm{ha}$, $P_{2}=112 \mathrm{~kg} P / \mathrm{ha}$ and $P_{3}=224 \mathrm{~kg} P / \mathrm{ha}$. Fresh and dry matter yield of corn plants grown on Lewisburg soil increased significantly with phosphorus fertilization. The field capacity treatment $\left(M_{1}\right)$ significantly outyielded the other two moisture treatments when $112 \mathrm{~kg} P / \mathrm{ha}$ was applied. At $224 \mathrm{~kg}$ $P / h a$ there was no significant difference in yield between $M_{1}$ and $M_{2}$ treatments, but both these treatments significantly outyielded the $M_{3}$ treatment. Corn plants grown on Nipe soil did not respond to phosphorus or moisture treatments. Phosphorus applications to Lewisburg soil significantly increased phosphorus uptake by corn plants. Phosphorus uptake was $3.89,21.60$ and $42.73 \mathrm{mg} /$ pot for 0,112 and $224 \mathrm{~kg} P$ treatments, respectively. An increase in moisture stress decreased $P$ uptake with $M_{1}$, $M_{2}$ and $M_{3}$ yielding $27.88,22.91$ and $17.42 \mathrm{mg} \mathrm{P/pot,} \mathrm{respectively.} \mathrm{Corn}$ plants grown on Nipe soil showed a slight increase in $P$ uptake with the application of $224 \mathrm{~kg} P / h a$, but this increase was not significantly different from that of the other two $P$ treatments. Nor did moisture stress affect $P$ uptake. The lack of response of corn plants to $P$ fertilization and moisture level of Nipe soil can be attributed to a high P fixing capacity of the soil.
\end{abstract}

\section{RESUMEN}

Efecto de los niveles de humedad y tasas de fósforo sobre la absorción de fósforo y el crecimiento del maiz

Se evaluó el efecto del contenido de humedad del suelo y aplicaciones de fósforo en el crecimiento del maíz (Zea mays L.) y la absorción de P en un experimento de tiestos bajo condiciones de invernadero. Los suelos incluidos en el estudio fueron Lewisburg (arenáceo, mixto, mésico, Typic Hapludalf) y Nipe (arcilloso, oxídico, isohipertérmico, Anionic Acrudox). Los niveles de humedad evaluados fueron $M_{1}=$ capacidad de campo, $M_{2}=$ fluctuación entre la capacidad de campo y $50 \%$ agua disponible y $M_{3}$ = fluctuación entre la capacidad de campo y el punto de marchitez. Los niveles de fósforo fueron: $P_{1}=0 \mathrm{~kg}$. $P /$ ha., $P_{2}=112 \mathrm{~kg}$. $P / \mathrm{ha}$. y $P_{3}=224 \mathrm{~kg}$.

'Manuscript submitted to Editorial Board 13 September 1990.

"Assistant Researcher, Department of Agronomy and Soils.

sProfessor, Department of Agronomy and Soils, The Ohio State University, Columbus, Ohio. 
P/ha. Las aplicaciones de P aumentaron significativamente los pesos fresco y seco de las plantas de maiz sembradas en el suelo Lewisburg.

El tratamiento de capacidad de campo $\left(M_{1}\right)$ superó significativamente - los tratamientos $M_{2}$ y $M_{3}$ en pesos fresco y seco cuando se aplicó $112 \mathrm{~kg}$. de P/ha. al suelo Lewisburg. Al aumentar la aplicación de P a $224 \mathrm{~kg}$. de P/ha. no se observó diferencia significativa entre $M_{1}$ y $M_{2}$, pero ambos tratamientos de humedad fueron significativement superiores al $M_{3}$. Las plantas de maiz sembradas en el suelo Nipe no mostraron respuesta significativa a los tratamientos de P o humedad del suelo. Las aplicaciones de f6storo de 0,112 y $224 \mathrm{~kg}$./ha. al suelo Lewisburg resultaron en una absorción de $P$ de $3.89,21.60$ y $42.73 \mathrm{mg}$./tiesto, respectivamente. La disminución en el contenido de agua disponible en el suelo redujo la absorción de $P$. La absorción de $P$ correspondiente a los fratamientos $M_{1}, M_{2}$ y $M_{3}$ fue $27.88,22.91$ y $17.42 \mathrm{mg}$. Itiesto, respectivamente. El maiz en el suelo Nipe aumentó la absorción de P de 0.82 a $1.24 \mathrm{mg} . /$ tiesto al aumentar la aplicación de 112 a $224 \mathrm{~kg}$. P/ha. Sin embargo, la diferencia en absorción no fue estadísticamente significativa. Tampoco se observó ningún efecto de los tratamientos de humedod en la absorción de $\mathrm{P}$ en este suelo. La poca fertilidad del suelo Nipe, así como una alta capacidad para adsorber $P$ pueden haber contribuido a la ausencia de una respuesta significativa a los tratamientos evaluados.

\section{INTRODUCTION}

There are three principal mechanisms by which nutrients in the soil may reach the surface of a growing root: the root may grow toward the nutrients; the nutrients may be carried to the root by mass-flow as the result of water absorption by the root; or the nutrients may diffuse from the soil to the root. These three mechanisms are dependent on soil water content to work properly. For example, rates of root extension are highly dependent on available water $(7,8,15)$, and moisture stress increases the shearing strength of soils and the mechanical impedance to root extension (9). Moisture stress would also reduce the transport of nutrients by mass flow if water absorption by the plant decreases, and by diffusion, if drying diminishes the thickness of the water films surrounding soil particles $(3,5,12)$. Besides soil moisture content, parameters such as soil texture $(2,11), \mathrm{pH}$, root morphology $(13,16,17)$ and plant age $(1,9)$ influence phosphorus absorption by plants.

$\mathrm{P}$ is made available to the plant root almost entirely by the process of diffusion $(3,6,10)$. Therefore, periods of water stress should decrease $\mathrm{P}$ absorption and restrict plant growth.

The work herein reported was carried out to evaluate the effect of moisture stress on corn growth and $\mathrm{P}$ uptake and to determine whether an increase in $\mathrm{P}$ rate would overcome the negative effects of moisture stress.

\section{MATERIALS AND METHODS}

Two soils, Lewisburg silt loam (fine, mixed, mesic, Typic Hapludalfs), and Nipe clay (clayey, oxidic, isohyperthermic, Anionic Acrudox) were selected for the study. Tables 1 and 2, respectively, present selected 
TABLE 1.-Physical properties of the soils

\begin{tabular}{lccccc} 
& \multicolumn{3}{c}{ Particle size distribution (\%) } & \multicolumn{2}{c}{ Moisture content (\%) } \\
\cline { 2 - 4 } \cline { 5 - 7 } Soil & Sand & Silt & Clay & FC & PWP \\
\hline Lewisburg silt loam & 14.3 & 66.5 & 19.2 & 28.4 & 15.3 \\
Nipe clay & 7.3 & 35.1 & 57.6 & 35.0 & 26.0 \\
\hline
\end{tabular}

' $F C=$ field capacity, $P W P=$ permanent wilting point.

physical and chemical properties of the soils. The moisture retention capacity of the soils was determined with ceramic plate extractors. The field capacity of Lewisburg soil was determined by setting the pressure in the extractor at 0.3 bar. However, for Nipe soil, 0.1 bar was used because this soil has a very short range of available water. The permanent wilting point of both soils was determined by setting the pressure in the extractor at 15 bars. Three moisture treatments were established: $\mathrm{M}_{1}=$ field capacity; $\mathrm{M}_{2}=$ fluctuation between field capacity and $50 \%$ available water; and $\mathrm{M}_{3}=$ fluctuation between field capacity and permanent wilting point.

Soil $\mathrm{pH}$ was measured in a 1:2 soil:water ratio, and available $\mathrm{P}$ was determined by the Bray- 1 method. The exchangeable cations $\left(\mathrm{K}^{-}, \mathrm{Ca}^{\prime 2}\right.$ and $\mathrm{mg}^{+2}$ ) were extracted with $1 \mathrm{~N}$ ammonium acetate at $\mathrm{pH} 7$ (14). $\mathrm{K}$ was determined by atomic emission and $\mathrm{Ca}$ and $\mathrm{Mg}$ by atomic absorption. $\mathrm{Fe}$ was extracted by the DTPA method, $\mathrm{Mn}$ with $0.1 \mathrm{~N}$ phosphoric acid and $\mathrm{Zn}$ with $0.1 \mathrm{~N} \mathrm{HCl}$. These elements were also determined by atomic absorption. The cation exchange capacity was determined by the ammonium acetate method (14).

The experiment was conducted under greenhouse conditions with a split plot design. The soils formed the main plots and were replicated three times. In addition to the three moisture treatments, three $P$ treatments were included: $P_{1}=0, P_{2}=112$ and $P_{3}=224 \mathrm{~kg} P /$ ha. Twenty-seven pots per main plot were included, each containing 1,816 grams of soil. All possible combination treatments for $\mathrm{P}$ and moisture were randomized within the main plots to form the subplots. $P$ fertilizer was mixed with the soil, and the pots were kept at field capacity for a week before planting. At planting time, both $\mathrm{N}$ and $\mathrm{K}$ were applied to the pots at a rate of $224 \mathrm{~kg} / \mathrm{ha}$. Five seeds of corn (Zea mays L.), Landmark hybrid C 550X were planted per pot. After germination the corn seedlings were thinned to two per pot.

We weighed the pots every day to monitor moisture loss. Pots from the field capacity treatment $\left(\mathrm{M}_{1}\right)$ were watered every day. For the other two treatments, $\mathrm{M}_{2}$ and $\mathrm{M}_{3}$, whenever the moisture content reached the corresponding lower limit (50\% available water or permanent wilting point), sufficient distilled water was added to increase the water content to field capacity. 
TABS, 2.-Chemical properties of the soils

\begin{tabular}{|c|c|c|c|c|c|c|c|c|c|c|c|c|}
\hline \multirow[b]{2}{*}{ Soil } & \multirow{2}{*}{ pH } & K & $\mathrm{Ca}$ & $\mathrm{Mg}$ & CEC & $\mathrm{Ca}$ & $\mathrm{Mg}$ & $\mathrm{K}$ & $P$ & Mn & $\mathrm{Fe}$ & $7 n$ \\
\hline & & \multicolumn{4}{|c|}{ meq $/ 100 \mathrm{~g}$} & \multicolumn{3}{|c|}{ \% Base saturation } & \multicolumn{4}{|c|}{ 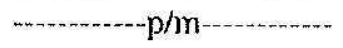 } \\
\hline $\begin{array}{l}\text { Lewisburg } \\
\text { silt loam }\end{array}$ & 5.6 & 0.30 & 7.56 & 2.39 & 15 & 51 & 15 & 2.1 & 5 & 17.5 & 177.8 & 101.8 \\
\hline Nipe clay & 5.9 & 0.04 & 1.12 & 0.35 & 5 & 22 & 7 & 0.9 & 2 & 3.5 & 12.8 & 1.0 \\
\hline
\end{tabular}

The corn plants were harvested 45 days after planting and the fresh and dry weights recorded. The oven-dry plant material was digested with a 1:1 $\mathrm{HNO}_{3} / \mathrm{HClO}_{4}$ acid mixture and analyzed for total $\mathrm{P}$ content by inductively coupled plasma spectrography. The data were statistically analyzed by analysis of variance and Duncan multiple range test.

\section{RESULTS AND DISCUSSION}

Nine days after planting, a dark purple color, characteristic of $\mathrm{P}$ deficiency, was observed on corn plants where no $\mathrm{P}$ was applied. The symptoms were more marked on plants growing on Nipe soil. By the end of the growing period (45 days after planting), all corn plants growing on Nipe soil showed $\mathrm{P}$ deficiency symptoms and their growth was extremely poor when compared to that of their respective counterparts on Lewisburg soil. P deficiency symptoms in plants growing on Lewisburg soil had disappeared by the end of the growing period.

TABLE 3.-Fresh and dry weight of com plants as affected by $P$ application and moisture level

\begin{tabular}{|c|c|c|c|c|}
\hline \multirow[b]{2}{*}{ Treatment } & \multicolumn{2}{|c|}{ Lewisburg silt loam } & \multicolumn{2}{|c|}{ Nipe clay } \\
\hline & Fresh weight & Dry weight & Fresh weight & Dry weight \\
\hline$P_{1} M_{1}^{1.2}$ & $33.00 e^{4}$ & $3.70 \mathrm{e}$ & $6.70 \mathrm{a}$ & $1.15 \mathrm{a}$ \\
\hline $\mathrm{P}_{1} \mathrm{M}_{2}$ & $23.00 \mathrm{r}$ & $2.63 \mathrm{e}$ & $6.30 \mathrm{a}$ & $1.00 \mathrm{a}$ \\
\hline$P_{1} M_{3}$ & $13.70 \mathrm{~g}$ & $1.79 \mathrm{e}$ & $6.30 \mathrm{a}$ & $0.78 \mathrm{a}$ \\
\hline$P_{2} M_{1}$ & $99.30 \mathrm{~b}$ & $16.23 \mathrm{~b}$ & $8.00 \mathrm{a}$ & $0.97 \mathrm{a}$ \\
\hline $\mathrm{P}_{2} \mathrm{M}_{2}$ & $82.30 \mathrm{c}$ & $9.86 \mathrm{~d}$ & $9.00 \mathrm{a}$ & $1.19 \mathrm{a}$ \\
\hline$P_{2} M_{3}$ & $66.70 \mathrm{~d}$ & $8.07 \mathrm{~d}$ & $6.30 \mathrm{a}$ & $0.88 \mathrm{a}$ \\
\hline$P_{3} M_{1}$ & $118.70 \mathrm{a}$ & $19.04 \mathrm{a}$ & $13.00 \mathrm{a}$ & $1.52 \mathrm{a}$ \\
\hline$P_{3 ;} M_{2}$ & $115.70 \mathrm{a}$ & $17.54 \mathrm{ab}$ & $13.70 \mathrm{a}$ & $1.66 \mathrm{a}$ \\
\hline $\mathrm{P}_{3} \mathrm{M}_{33}$ & $94.70 \mathrm{~b}$ & $13.23 \mathrm{c}$ & $10.30 \mathrm{a}$ & $1.25 \mathrm{a}$ \\
\hline
\end{tabular}

$1 P_{1}, P_{2}$ and $P_{3}$ are phosphorus rates $(0,112$ and $224 \mathrm{~kg} / \mathrm{ha}$, respectively).

${ }^{2} \mathrm{M}_{1}, \mathrm{M}_{2}$ and $\mathrm{M}_{3}$ are moisture levels (field capacity, fluctuation between field capacity and half available water, and fluctuation between field capacity and permanent wilting point).

"Means in colums followed by the same letter do not differ significantly at the $5 \%$ level by the Duncan Multiple Range Test. 


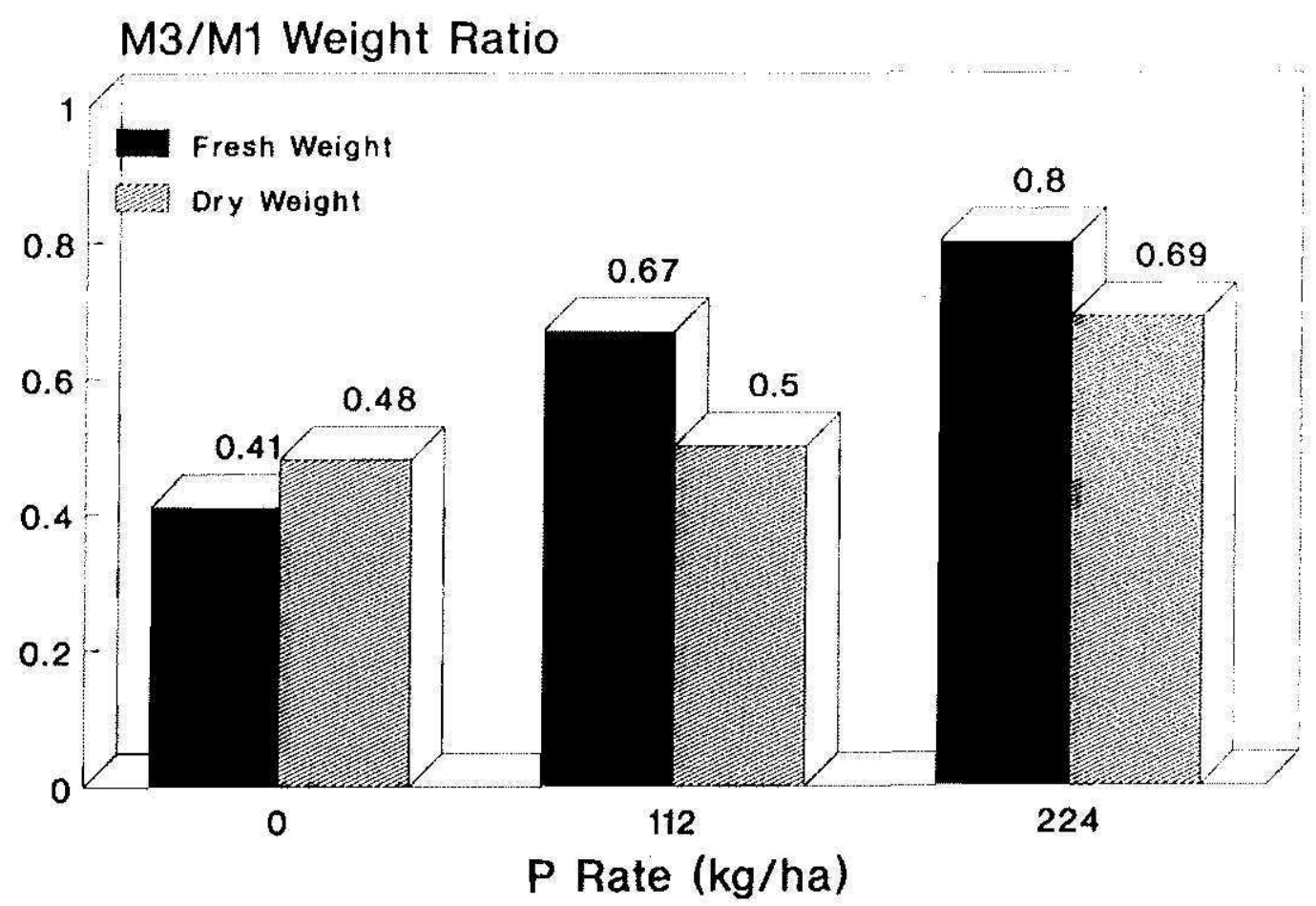
soil.

Fig. 1.-Effect of $P$ rate on the $M_{3} / M_{1}$ weight ratio of corn plants growing on Lewisburg

Fresh and dry matter yield of corn plants increased significantly in Lewisburg soil because of the $P$ rate (table 3). There was no significant difference in dry matter yield among moisture treatments when no $P$ was applied, but moisture stress decreased fresh yield significantly. The field capacity treatment $\left(M_{1}\right)$ resulted in a significant increase of fresh and dry matter over the other two moisture treatments $\left(\mathrm{M}_{2}\right.$ and $\left.\mathrm{M}_{3}\right)$, when 112 $\mathrm{kg} \mathrm{P} / \mathrm{ha}$ was applied. However, at the level of $224 \mathrm{~kg}$ P/ha, there was no significant difference in fresh and dry matter yield between $M_{1}$ and $M_{2}$ treatments, but the $\mathrm{M}_{3}$ treatment was significantly lower in both cases. The similar fresh and dry matter yield observed for $\mathrm{M}_{1}$ and $\mathrm{M}_{2}$ treatments at the $224 \mathrm{~kg}$ P level suggests that the increase in applied $\mathrm{P}$ helped the plant to tolerate water stress. Such an effect can be clearly seen when the $M_{3} / M_{1}$ fresh and dry weight ratio is considered (fig. 1). The closer to 1 the $M_{3} / M_{1}$ value , the less the moisture stress effect. The $\mathrm{M}_{3} / \mathrm{M}_{1}$ fresh weight ratio values for 0,112 and $224 \mathrm{~kg}$ P/ha treatments were $0.42,0.67$ and 0.80 , respectively. The dry weight ratio values were $0.48,0.50$ and 0.70 for the same treatments, in the same order.

Corn plants growing on Nipe clay did not respond to $\mathrm{P}$ or moisture treatments. Although there was an increase in dry weight at the highest $\mathrm{P}$ rate $(224 \mathrm{~kg} / \mathrm{ha})$, it was not significantly different from the others. Apparently, the Nipe soil has a strong capacity to absorb and retain $P$, thus making it unavailable to the plant. 
TABLE 4.-Phosphomes concentration and uptake as affected by $P$ rate and moisture level

\begin{tabular}{|c|c|c|c|c|}
\hline \multirow[b]{3}{*}{ Treatment } & \multicolumn{2}{|c|}{ Lewisburg silt loam } & \multicolumn{2}{|c|}{ Nipe Clay } \\
\hline & P conc. & Puptake & P conc. & Puptake \\
\hline & $(\mathrm{mg} / \mathrm{g})$ & (mg/pot) & $(\mathrm{mg} / \mathrm{g})$ & (mg/pot) \\
\hline$P_{1} M_{1}{ }^{\prime}$ & $1.53 \mathrm{~d}^{2}$ & $5.67 \mathrm{~d}$ & $0.79 a$ & $0.91 \mathrm{a}$ \\
\hline$P_{1} M_{2}$ & $1.48 d$ & $3.89 \mathrm{~d}$ & $0.94 a$ & $0.94 \mathrm{a}$ \\
\hline$P_{1} M_{3}$ & $1.17 \mathrm{e}$ & $2.10 d$ & $0.78 a$ & $0.61 \mathrm{a}$ \\
\hline$P_{2} M_{1}$ & $1.84 \mathrm{c}$ & $29.90 \mathrm{~b}$ & $0.83 a$ & $0.82 a$ \\
\hline $\mathrm{P}_{2} \mathrm{M}_{2}$ & $2.08 \mathrm{~b}$ & $20.27 \mathrm{c}$ & $0.80 \mathrm{a}$ & $0.95 a$ \\
\hline$P_{2} M_{3}$ & $1.82 \mathrm{c}$ & $14.62 \mathrm{c}$ & $0.78 a$ & $0.68 \mathrm{a}$ \\
\hline$P_{3} M_{1}$ & $2.53 a$ & $48.08 \mathrm{a}$ & $0.83 \mathrm{a}$ & $1.26 \mathrm{a}$ \\
\hline $\mathrm{P}_{3} \mathrm{M}_{2}$ & $2.55 a$ & $44.57 \mathrm{a}$ & $0.80 a$ & $1.33 \mathrm{a}$ \\
\hline $\mathrm{P}_{3} \mathrm{M}_{3}$ & $2.68 \mathrm{a}$ & $35.53 \mathrm{~b}$ & $0.91 \mathrm{a}$ & $1.13 a$ \\
\hline
\end{tabular}

'See table 3 for treatment description.

"Means in columns followed by the same letter do not differ significantly at the $5 \%$ level by the Duncan Multiple Range Test.

P uptake by corn plants grown on Lewisburg soil increased linearly with $P$ rate, following the same pattern of dry weight (table 4). There was also a significant increase in $\mathrm{P}$ concentration with increase in $\mathrm{P}$ rate. No significant differences in $\mathrm{P}$ uptake were found between moisture treatments when no $\mathrm{P}$ was applied. However, when $112 \mathrm{~kg} \mathrm{P} / \mathrm{ha}$ was applied, a significant increase in $\mathrm{P}$ uptake was observed as moisture stress decreased. $\mathrm{P}$ uptake was $14.62,20.27$ and $29.90 \mathrm{mg} / \mathrm{plant}$ for $\mathrm{M}_{3}$, $\mathrm{M}_{2}$ and $\mathrm{M}_{1}$, respectively (table 4). At $224 \mathrm{~kg} \mathrm{P} / \mathrm{ha}$, there was no significant difference between $M_{1}$ and $M_{2}$, but $P$ absorption under these two moisture treatments was significantly higher than under $\mathrm{M}_{3}$. $\mathrm{P}$ uptake by corn plants grown on Nipe soil was not affected by $\mathrm{P}$ or moisture treatments.

The effect of moisture stress on $\mathrm{P}$ concentration (Lewisburg soil) did not follow a specific pattern. At $P_{1}$ (No $P$ applied), an increase in moisture stress to the permanent wilting point $\left(\mathrm{M}_{3}\right)$ reduced significantly $P$ concentration. However, when $112 \mathrm{~kg} P / \mathrm{ha}$ was applied, $\mathrm{M}_{1}$ and $\mathrm{M}_{3}$ showed the same $P$ concentration but were significantly outyielded by the $M_{2}$ treatment.

The overall effect of $\mathrm{P}$ and moisture treatments on $\mathrm{P}$ uptake is presented in figures $2 \mathrm{a}, 2 \mathrm{~b}, 3 \mathrm{a}$ and $3 \mathrm{~b}$. Average $\mathrm{P}$ uptake by corn plants grown on Lewisburg soil was $3.89,21.60$ and $42.73 \mathrm{mg} /$ pot for 0,112 and $224 \mathrm{~kg} \mathrm{P} /$ ha, respectively (fig. 2a). There was a slight increase in $\mathrm{P}$ uptake by corn plants grown on Nipe clay when $224 \mathrm{~kg} \mathrm{P}$ was applied (1.24 mg/pot), but this uptake was not significantly different from that of the other two P treatments. Increasing moisture stress decreased significantly $\mathrm{P}$ uptake by corn plants grown on Lewisburg soil. The $\mathrm{M}_{3}$ 


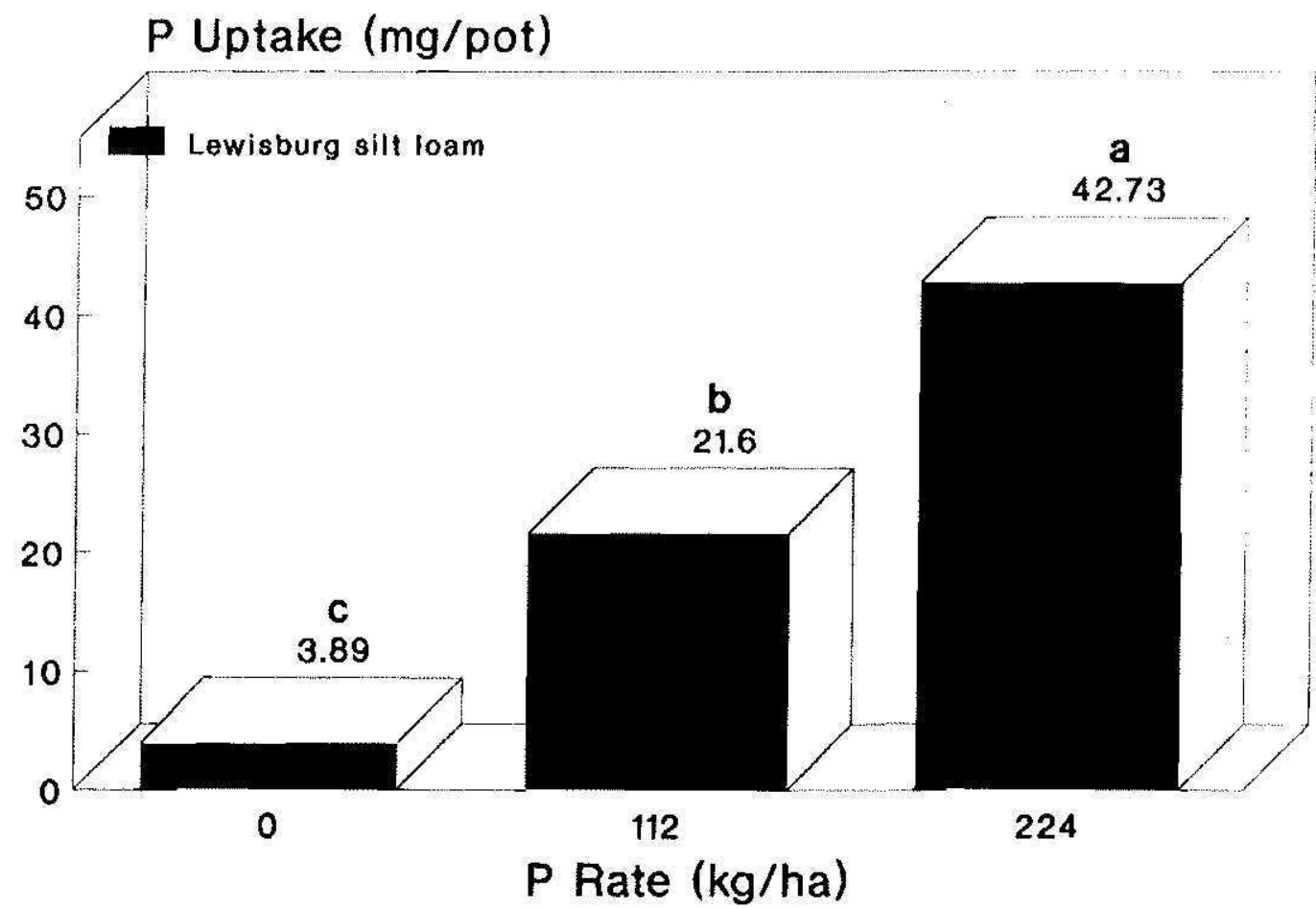

Fig. 2a.-Effect of $P$ rate on $P$ uptake by corn plants.

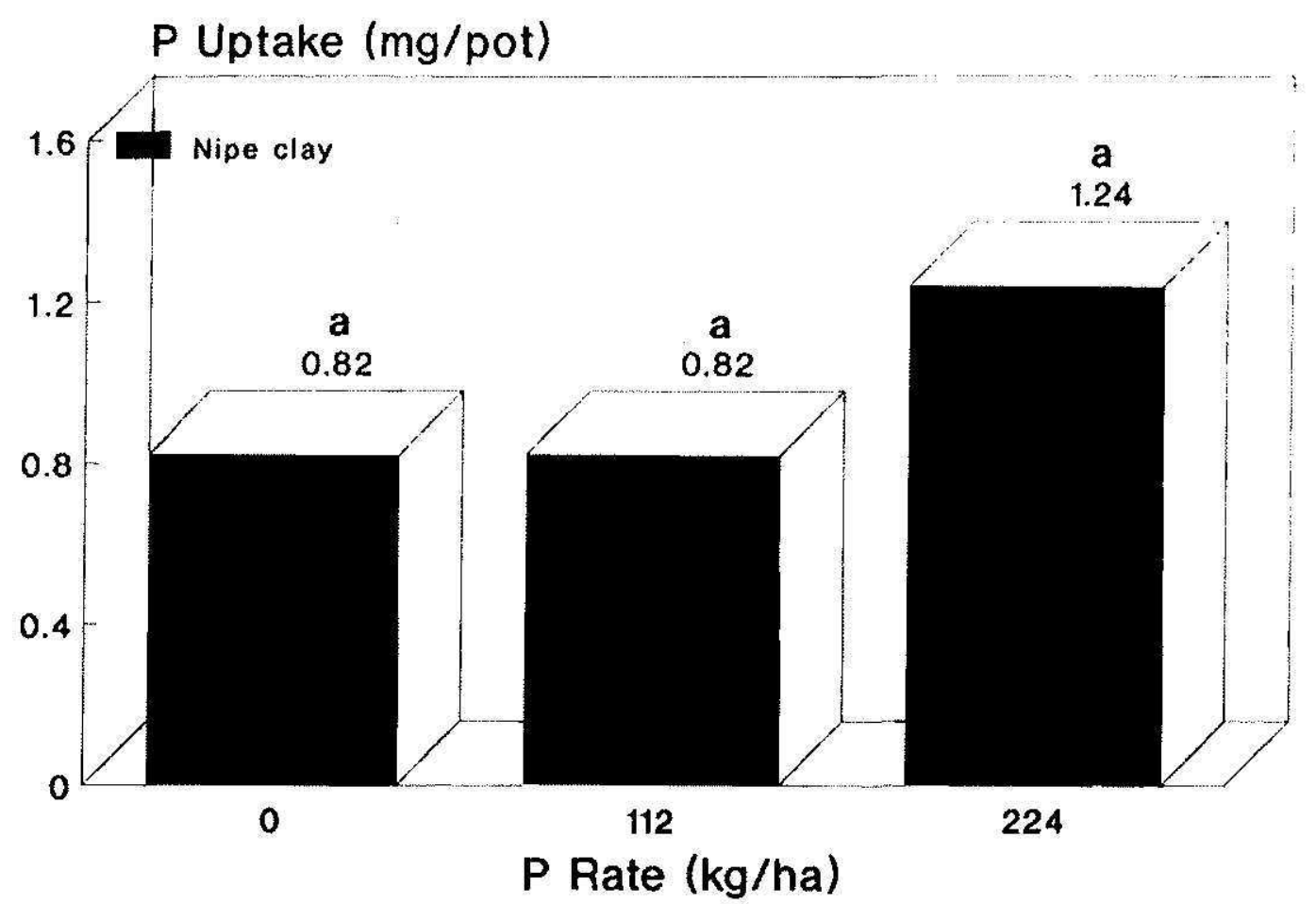

Fig. 2b.-Effect of $P$ rate on $P$ uptake by corn plants. 


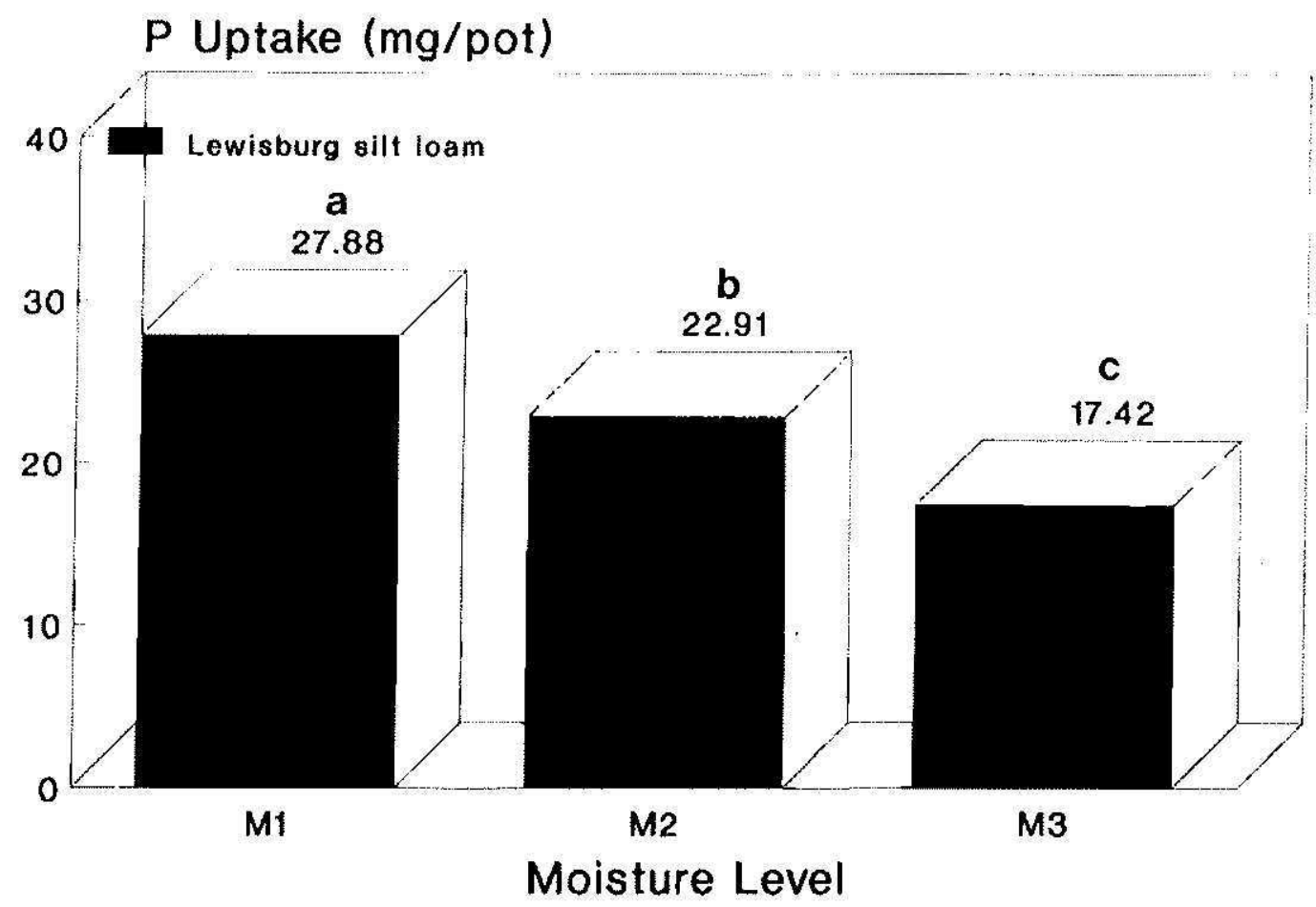

Fig. 3a.-Effect of moisture level on P uptake by corn plants.

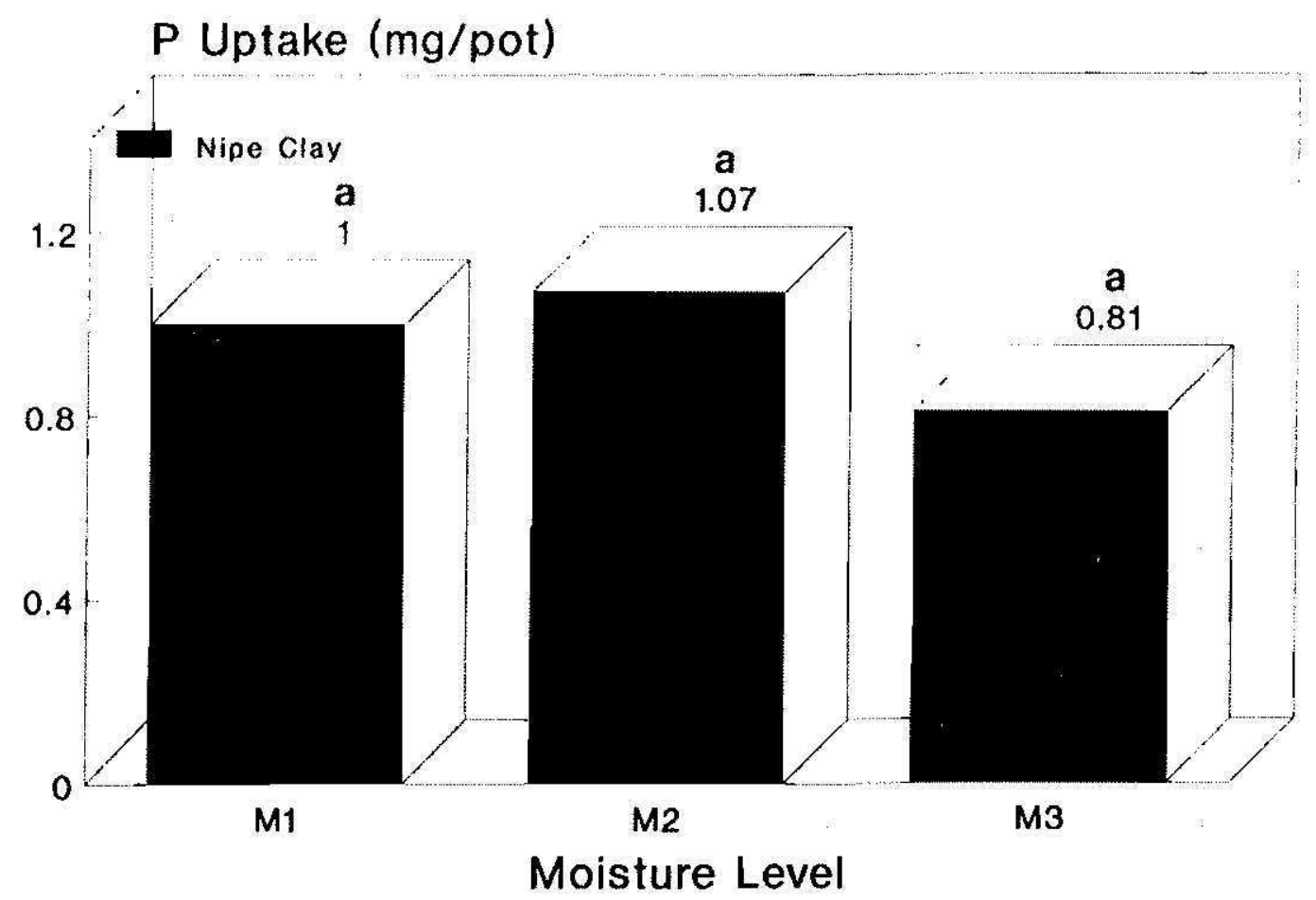

Fig. 3b.-Effect of moisture level on $P$ uptake by corn plants. 
treatment resulted in a $P$ uptake of $17.42 \mathrm{mg} /$ pot, whereas the $M_{1}$ and $\mathrm{M}_{2}$ treatments yielded 27.88 and $22.91 \mathrm{mg} / \mathrm{pot}$, respectively.

The differences in dry matter yield and $\mathrm{P}$ uptake between soils were dramatic. Corn growth on Lewisburg soil was excellent at 112 and 224 $\mathrm{kg} / \mathrm{ha}$ of applied P; thus the P requirement of the crop was fulfilled. The lack of response of corn to $P$ level or moisture observed in Nipe clay can be attributed to the low fertility level of this soil (table 2), and to its high $P$ fixing capacity. Fox (7) reported a $\mathrm{P}$ adsorption capacity for Nipe soil of $660 \mu \mathrm{g} / \mathrm{g}$ of soil and $1200 \mu \mathrm{g} / \mathrm{g}$ of clay at a solution concentration of 0.2 $\mathrm{p} / \mathrm{m}$. Among eleven soils studied (one Inceptisol, four Ultisols and six Oxisols), Nipe ranged second in P adsorption capacity.

Plant growth was clearly inhibited when moisture stress was induced in Lewisburg soil. The lack of available $\mathrm{P}\left(\mathrm{P}_{1}\right)$ restricted growth so severely that the corn plants were not capable of utilizing available water properly; thus, no effect of moisture stress was observed. The application of $112 \mathrm{~kg} \mathrm{P} / \mathrm{ha}$ increased root growth (data not shown) and plant growth, which resulted in a more efficient use of available water. Corn plants planted on Nipe soil were severely limited by lack of available nutrients and the effect of moisture stress could not be elucidated.

The decrease in $\mathrm{P}$ uptake under moisture stress can be attributed to a decrease in $\mathrm{P}$ diffusion in the soil and to the restricted root growth $(3,4)$. Root development and capacity to absorb nutrients are also affected by moisture stress. Peters (15) showed that elongation of corn roots was favored by low levels of water stress. Barley (5) observed that water stress may also increase the mechanical impedance to root extension. The increase in $\mathrm{P}$ rate from 0 to $224 \mathrm{~kg} / \mathrm{ha}$ apparently favored $\mathrm{P}$ diffusion and enhanced root development. This was reflected in a larger $\mathrm{P}$ absorption and better plant growth under conditions of water stress. The results suggest that more $P$ needs to be applied to crops during periods of moisture stress in order to provide optimum $\mathrm{P}$ nutrition.

\section{LITERATURE CITED}

1. Anghinoni, I., V. C. Baligar and S. A. Barber, 1981. Growth and uptake rates of P, $\mathrm{K}, \mathrm{Ca}$, and $\mathrm{Mg}$ in wheat. $J$. Plant Nutr. 3 (6): 923-33.

2. Baldovinos, F, and G. W. Thomas, 1967. The effect of soil clay content on phosphorus uptake. Soil Sci. Soc. Am. Proc. 31: 680-82.

3. Barber, S. A., J. M. Walker and E. H. Vasey, 1963. Mechanisms for the movement of plant nutrients from the soil and fertilizer to the plant root. J. Agric. Food Chem. 11: 204-7.

4. Barber, S. A., 1978. Growth and nutrient uptake of soybean roots under field conditions. Agron. J. 70: 457-61.

5. Barley, K. P., 1963. Influence of soil strength on growth of roots. Soil Sci. 96: 175-80.

6. Bhat, K. K. S. and P. H. Nye, 1973. Diffusion of phosphate to plant roots in soil. I. Quantitative autoradiography of the depletion zone. Plant Soil 38: 161-75.

7. Fox, R. L., 1982. Some highly weathered soils of Puerto Rico, 3. Chemical properties. Geoderma 27: 139-76. 
8. Gingrich, J. R. and M. B. Russell, 1956. Effect of soil moisture tension and oxygen concentration on the growth of corn roots. Agron. J. 48: 517-20.

9. — and - - 1957. A comparison of effects of soil moisture tension and osmotic stress on root growth. Soil Sci. 84: 185-94.

10. Jungk, A. and S. A. Barber, 1975. Plant age and the phosphorus uptake characteristies of trimmed and untrimmed corn roots sy'stems. Plant Soil 42: 227-35.

11. Lewis, D. G. and J. P. Quirk, 1967. Phosphate diffusion in soil and uptake by plants: III. P movement and uptake by plants as indicated by P autoradiography. Plant Soil 26: 445-53.

12. Mahtab, S. K., C. L. Godfrey, A. R. Swoboda and G. W. Thomas, 1971. Phosphorus diffusion in soils: 1 . The effect of applied P, clay content and water content. Soil Sci. Soc. Am. Proc. 35: 393-97.

13. — A. B. Swoboda, C. L. Godfiey and G. W. Thomas, 1972. Phosphorus diffusion in soils: II. The effect on phosphorus uptake by plants. Soil Sci. Soc. Am. Proc. 36: $55-7$.

14. Nielsen, N. E. and S. A. Barber, 1978. Differences among genotypes of corn in the kinetics of P uptake. Agron. J. 70: 695-98.

15. Page, A. L., R. H. Miller and D. R. Keeney, 1982. Methods of Soil Analysis. Part 2: Chemical and Microbiological Properties. Second Ed. Monograph No. 9. Am. Soc. Agron., Madison, Wisconsin.

16. Peters, D. B., 1957. Water uptake of corn roots as influenced by soil moisture content and soil moisture tension. Soil Sci. Soc. Am. Proc. 21: 481-84.

17. Schenk, M. K. and S. A. Barber, 1979. Phosphate uptake by corn as affected by soil characteristics and root morphology. Soil Sci. Soc. Am. J. 43: 880-83. 